\title{
Matthew Giles
}

\section{Colorblindness in the Public Consciousness}

\begin{abstract}
This paper explores the relationship between the public narrative created by dominant socio-ethnic groups and the people being represented in that discourse through the frame of racial colorblindness. Colorblind ideology pervades American public discourse and negatively affects social perception of race in conflict situations. Although some well-intentioned aspects of colorblind policy allow for racial diversity, colorblind ideology is insufficient to protect the rights of minorities and underprivileged groups. An analysis of the philosophy behind racial colorblindness illustrates how groups reinforce privilege and recognizes the reasons why the ideal of racial colorblindness persists despite flaws and inaccuracies. Three individual statements from key figures in Ferguson demonstrate this racial colorblindness, and at times even specifically mention colorblind ideology. This paper unpacks the cultural understanding of racial colorblindness, recognizes the perceptions and perspectives of the speakers, and demonstrates the problems that emerge when the myth of racial colorblindness is left unchecked.
\end{abstract}

KEYWORDS: racial colorblindness, narrative identity, intergroup communication, Ferguson

$\not a$

In an October 2014 interview between the Tonight Show host Jon Stewart and FOXNews Anchor Bill O'Reilly, the conservative Republican O'Reilly claimed: "There is no such thing as white privilege." He expresses genuine disbelief in the concept and cited: "The most powerful man in the world is a black American, and the most powerful woman in the world, Oprah Winfrey, is a black woman!" This perspective is part of a larger worldview that does not acknowledge race as a significant social factor, despite overwhelming racial disparities and social groups that are entirely divided along racial lines. In Ferguson, Missouri, the recent fatal shootings by white police against unarmed black men have spurred protests and occasional riots, but despite continued evidences of racism and structural disadvantage based on race, Ferguson's Mayor John Knowles has gone on record stating that "there's not a racial divide in Ferguson." In the face of what many news networks are labelling as race riots, the issue of race is on the forefront in Ferguson, but this narrative of 
"colorblindness" remains prevalent in mainstream media discourse, highlighting the spaces of privilege in American social structure.

These examples illustrate both the prevalence and the folly of contemporary conceptualizations of racial colorblindness. This paper explores how the narrative of colorblindness evolved through the second half of the 20th century, and its subsequent metonymic function to justify the empowerment of privileged social groups in the United States. Using a selection of public statements that reference colorblindness made by influential public figures in the spectacle of Ferguson, I demonstrate how colorblind ideology is used to defend racist behaviors. To this end, I look at two distinct applications of colorblindness: first, the way that social policy is shaped by colorblind ideology; and second, how the performativity of ostensibly colorblind perspectives disadvantages the narrative identity synthesis of minority groups.

My approach is grounded in the cultural semiotics and social constructivist perspectives, which recognize that the culture, as typified by "the works and practices of intellectual and... artistic activity" of a group, is a signifying system constituted by signifying practices, producing and organizing meaning through the use of signs. From this social constructivist perspective, the media narratives in Ferguson construct and reconstruct government and social policy, sociocultural structures, and individual interpretations of culture (Sayer 2000). It is essential to understand this phenomenon as dialectic between the resilience of individual narratives and the ubiquity of organizations and networks that reinforce opposing narratives. This outlook frames the post-shooting governmental actions in Ferguson as more than simple changes in policy. The social constructivist perspective explains that these changes in public policy demonstrate a dramatic reorganization of the network of social practices that dictate how the people of Ferguson perceive themselves both within and outside of their community (Hall 1994). Put simply, both the protests and the social commentary changed the intergroup dynamics of living in Ferguson.

\section{Racial Colorbindness in the United States}

To understand what it means for the residents and government officials in Ferguson to be colorblind, the changing shape of colorblind racial ideology in the United States provides important context. The public notion of colorblindness has a far more complex history than can be summarized in a few paragraphs, but it remains important to demonstrate how statements about equal rights are not endorsements of colorblindness. Today, political pundits (such as those mentioned previously) often rewrite the context of past colorblind policy to fit their own perspective. During the Civil Rights Movement of the 1960s in the United States, Martin Luther King Jr. and others expressed the need for black skin to no longer be criminalized and for black lives to no longer be oppressed. Dr. King's famous I Have a Dream speech included the line: "I have a dream that my four little children will one day live in a nation where they will not be judged by the color of their skin, but by the 
content of their character." He sought to end black oppression, but the way he is characterized by the proponents of colorblind ideology is disingenuous. As an avid proponent of Affirmative Action, King hoped to benefit disadvantaged groups through positive discrimination. King explained in a 1965 interview that he was not advocating for all of society to turn a blind eye to the color of each person's skin, but instead believed that "a society that has done something special against the Negro for hundreds of years must now do something special for the Negro." King's activism for reparative treatment policies based on race belies any false notion of supposed racial colorblindness.

Concurrent to King's activism during the Civil Rights Movement, presidential administrations in the United States enacted legislation that officially forbade discrimination in the workplace. Two years after King's historic speech, the Johnson administration strengthened Affirmative Action laws to no longer simply criminalize discrimination, but to also "actively correct the effects of past and present discrimination." Despite his efforts that were anything but colorblind, the words of King and other historic figures are often reshaped to fit incongruous modern narratives, and even though soundbites from King's Dream have been appropriated to support racial colorblindness, King himself did not ignore race as a significant social factor. This trend of reappropriating the legacy of Martin Luther King Jr. has been noted by scholars of rhetoric and social discourse (see Baldwin 2014; Fluker 2010; Kirk-Duggan 2013; West 2008). In the book The Domestication of Martin Luther King Jr., Lewis Baldwin lambasts how contemporary white conservatives "like [Beck], Fallwell, Gingrich, and others before him, simply used King as a kind of sacred endorsement for the advancement of [their] own political and moral agenda" (24).

\section{Colorblindness in the Legal System}

Colorblindness is an essential part of the American legal system, which has undergone dramatic changes towards inclusiveness since the nation's inception. Where once voting rights were limited based on race, property-ownership, gender, religion, education, and parentage, systematic reforms have made voting rights much more "colorblind." Similarly, anti-discrimination policies strive to create a social environment that does not reward or punish people for their sexuality, skin colour, gender, or religion. Although no governmental policy has the capability to erase racism or any other form of oppression, these laws are created to help ensure that governments do not oppress groups of people based on the colour of their skin, while simultaneously reflecting the history of oppression experienced by people of colour. Despite the significant benefit of colorblind ideology in the legal system, there are problematic precedents set when the narrative of colorblindness is internalized by the people within the society. When power groups refuse to officially acknowledge race, the effects of oppression do not decline, but merely adapt to new structures, as discussed by modern feminists and other civil rights activists. 
The beneficial effects of legal colorblindness are often negated by institutional processes that maintain and reify inequality. In her book, The Velvet Glove: Paternalism and Conflict in Gender, Class, and Race Relations, Mary Jackman recognizes that racial imbalance often comes from these institutional processes, often "without active participation by individual whites, and hidden from their view" (1994: 137). In modern race relations in the United States, prototypical stereotypes of prejudice are uncommon, as both the omnipresence of recording technology and social standards of political correctness have decreased the frequency of displays of explicit racism. However, despite the liberalization of traditional race attitudes since the Civil Rights Movement, "whites continue to strongly oppose public policies that are intended to bring about greater racial equality" (DiTomasso, Parks-Yancy and Post 2002: 5). This allows the privileged group to systematically maintain racial disparity without any overtly racist individuals expressing or even feeling specific animosity towards anyone else based on race.

The problems inherent to racial colorblindness result from racial privilege, as minorities in the United States do not experience colorblindness in regards to their own race. However, if minorities experience racial prejudice even though white people claim liberalized attitudes towards race, then how exactly is this racism being perpetuated? In his essay Talking Past Each Other: Black and White Languages of Race, Bob Blauner argues that the word racism has shifted over time and that there are such different socially accepted meanings of racism that "blacks and whites often talk past each other" (2001: 194). In a world of structuralized racism, much focus is given to individual attitudes on race, which often has little effect on large-scale intergroup relations. Mary Jackman explains that the socially individualistic perspective in modern Western society allows people who are surrounded by racism to focus on their own individual lack of targeted animosity instead of recognizing larger cultural patterns. By interpreting racial attitudes as the result of individual choices and values, it takes attention away from the power relations that exist between groups that both shape attitudes and moderate them (DiTomasso, Parks-Yancy, and Post 2002: 8).

It is essential to note that a focus on negative interactions does not allow for a complete understanding of privilege and oppression, as racial oppression is not defined exclusively by slurs, aggression, or violence. Scholars have documented how positive in-group interactions privilege dominant group members at the expense of minorities (Bonilla-Silva 2006; Goodman 2001; Powell, Branscombe, \& Schmitt 2005). In an article in the Arizona Law Review, Dr. Anne McGinley explains that individual acts of discrimination are codified and illegal, whereas favouritism is generally accepted, which causes a false negative in white perceptions of racism. This phenomenon, known as white privilege, can be defined as an unearned advantage that benefits individuals who are considered "white" in a racially stratified society, which is generally unacknowledged by white individuals (Neville, Worthington, \& Spanierman 2001). 
In an ongoing series of studies that began in the 1980s, Gaertner and Dovidio conducted research with college-age white students that specifically measured how likely they were to favour other white people in their interactions. For these test subjects, acting with purposeful disfavour toward blacks was perceived as wrong and was generally uncommon (04); however, they were much more likely to support and aid other white individuals (76). DiTomasso, Parks-Yancy and Post explain that white advantage is often difficult to perceive because attribution error allows an individual to credit their own personal characteristics for their success while minimizing external factors that may have contributed to life outcomes. Similarly, this in-group privileging behavior is often associated with friendships, prior professional and educational association, and many other interactions that are not immediately apparent as being racially motivated. It is through these relationships that are not necessarily perceived to be racially motivated that "whites can, therefore, believe themselves to be innocent bystanders to black disadvantage" (DiTomasso, ParksYancy, and Post 1997: 6).

\section{Notable Statements from Ferguson}

These factors may explain why many people feel comfortable passively existing in a world surrounded by racism, but some statements from notable figures in Ferguson demonstrate more than simple acceptance of racial disparity. They demonstrate willful disregard of race, or an effort to conform to a perceived standard of colorblindness. It must be understood that supposed colorblindness is often much more comfortable for people in privileged positions, even if a purposeful and critical lens must be applied to these conversations. Cheris Kramarae opens her insightful text on social labels by explaining that "talking about race, class, and gender together is not easy, and not even always desirable. These systems have important historical and contemporary differences as well as connections. Each needs our concentrated, critical attention" This intersectional focus is required to understand both the culture which acts as a signifying system and the pre-existing racial narratives that dialectically structure the daily life of the people living in Ferguson.

\section{Case 1}

"None of our city's residents believe that there is a racial divide in Ferguson. I believe that to be the case still. There is not a racial divide in the city of Ferguson. That is the perspective of all residents in our city, absolutely...Allegations that Ferguson has experienced racial tensions during our history are absolutely ridiculous." -- James Knowles, Ferguson City Mayor

When Mayor Knowles publicly claimed that not only was he unaware of any racial divide in his city, but that none of the residents would believe there to be any racial divide, he surprised both the national media and his local community. In efforts to later explain his statements, Mayor Knowles said that "most residents in Ferguson are going about their daily lives, and this is simply not an issue for them." 
This blindness is explained by Peggy McIntosh, who wrote about the "invisible weightless knapsack of special provisions...codebooks...clothes, tools, and blank checks" that make up white privilege. She explains that this social advantage is both "denied and protected, but alive and real in its effects." Unlike Mayor Knowles, she recognizes that in her own life, "as a white person... [she had] been taught about racism as something that puts others at a disadvantage, but had been taught not to see one of its corollary aspects, white privilege, which puts [her] at an advantage" (McIntosh 1989: 5).

McIntosh explains how people who hold privilege are able to enjoy it without recognizing the dramatic advantages that they hold over their peers. Because these advantages are not earned, they commonly go unacknowledged and are taken for granted. Given that Mayor Knowles works in a city where the majority of the residents feel dissatisfied with the way that the government has been run, there are key factors that allow him to ignore the racial divide. The Mayor of the city appointed the white Chief of Police, and the city of Ferguson has six city council positions, five of which are held by white people. Similarly, Mayor Knowles works with the local school board, where all but one of the seven board members are white. The only black member of the school board is the first black person to hold that position, having been elected in April of 2014. The mayor's insulation from his constituents continues the pattern of social constructivism; it recreates the pattern of white privilege while keeping black voices at a distance, reifying the cycle of under-representation.

Being white in Ferguson allows an individual to have a drastically different experience than black citizens. Branden Turner, a black barber in Ferguson, often sees police sit outside his shop, "routinely waiting for customers to leave so they could... search for drugs, or ask them for identification so they could run a background check." Conversely, Peter Tries, a white shop-owner living in Ferguson, claims that "this whole thing is getting blown out of proportion. There's never been any kind of race thing here. It's something I never even think about." Race may not be something that local white citizens spend much time worrying about, but the same cannot be said for the black people who live in the same area today that was once officially recorded on the state registrar as "Little Africa" (Anderson 2014). The lives of people living in black communities in North County St. Louis have been shaped by race, as white flight has built government infrastructure for small towns. Throughout the history of the county, small towns composed of white-majority communities have been chartered and then subsequently abandoned and left financially unviable when white homeowners moved to new areas priced and zoned out of reach of the black community. 


\section{SHIFT IN FERGUSON RESIDENTS}

Percentage of black and white residents in Ferguson, Mo.

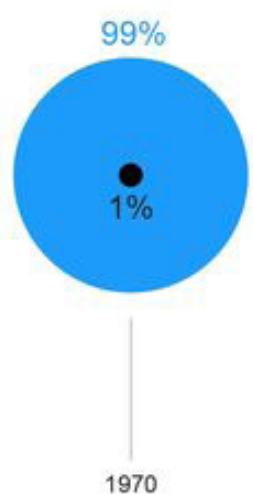

1970

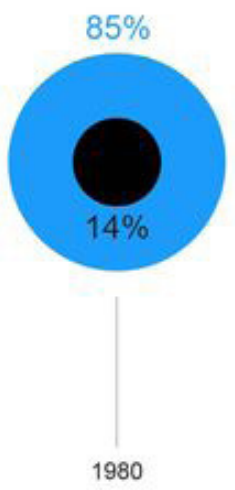

1980

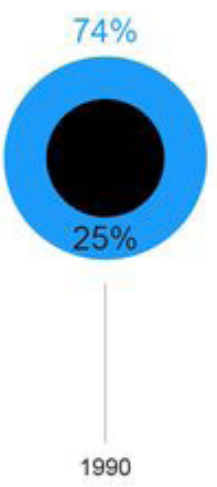

1990

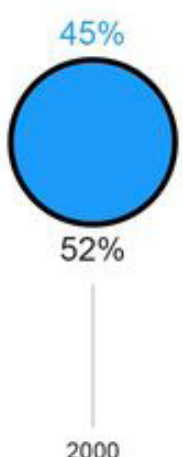

2000

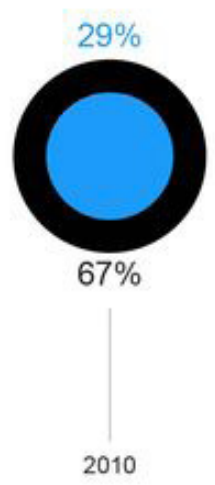

USATODAY
WHITE

BLACK

Mayor Knowles' sentiments are echoed on the city of Ferguson's official webpage, which provides a historical timeline of the city, noting important historical events, such as the founding of the Ferguson railroad station in the late 1800s, or the establishment of the Wabash Club, a recreational park built for employees of the railroad featuring a whites-only officer's club on-site. The timeline makes special note of the year 1900, where it highlights that the "former slaves of Thomas January and other slaves freed after the Civil War contributed to the early establishment of a racially diverse population." The city's definition of "racially diverse" seems suspect however, as up until 1970, census data records the city to have been 99 per cent "anglo" (Firozi 2014) ${ }^{1}$. The next 40 years heralded dramatic demographic changes in Ferguson. In the 1980 census, 85 per cent of the city's population identified as white. By 1990, the percentages of white citizens in Ferguson dropped another 10 per cent, down to 74 per cent of the town reporting as white/non-hispanic, with a 25 per cent black population. Over the next 20 years, those numbers interposed, with the white population plummeting to 29 per cent in 2010, and the black population rising to nearly 70 per cent. Compared to many cities in suburban St. Louis, Ferguson absolutely has reasons to boast about their diversity, but it is disingenuous to attribute to the town an "early establishment of a racially diverse population" by citing a legacy of racial tolerance.

Coming from the almost exclusively white government of Ferguson, statements such as these help to breed resentment and demonstrate the disconnect between 
the city's leadership and the people. While the statements are problematic, they cannot simply be attributed to racism or bigotry because the people involved are not directly exposed to racial disparity. Through the social structure that they have both inherited and constructed, the town officials simply do not see race as a problem. Because even "noticing" race opens an individual up to allegations of racism and stereotypical associations (Greenwald \& Banaji 1995), elected officials dismiss race as a formal consideration entirely so as to avoid the possibility of being perceived as engaging in discriminatory behavior (Dovidio et al.2002). This strategy is eminently defensible, as an individual who never admits to perception of race cannot be proven to have acted based on racist motivations; however it does nothing to address racial issues that already exist.

\section{Case 2}

"The statistics you hear about the Ferguson Police Department on the mainstream media aren't actually correct. There are four African American Police Officers, not three. The discrepancy may have been because we really don't see black or white among our colleagues." -- Timothy Zoll, Public Relations Officer, Ferguson Police Department

Timothy Zoll has spoken with the media repeatedly about the number of black and white officers serving in the town of Ferguson. While the city of Ferguson is not the worst offender ${ }^{2}$ in St. Louis County in regards to the percentage of white cops doing police work in mostly black towns, records show that 50 of the town's 53 police officers identified as white in their applications to the police department, with only 3 black officers on active duty. Apparently, one of the 50 officers also identifies as black, bringing the total of officers up to 4 , approximately 7.5 per cent.

Statements like the above quote from Zoll attempt to ignore race, supposedly as a means to overcome the negative impact of social prejudice. These attempts are not simply unsuccessful, but can be counter-productive as well. In a situation where the percentage ratio of white-to-black people is different between the citizens and the police by a factor of 10 , race is obviously an issue, even if the department does not believe that race is a contributing factor for employment as a law enforcement officer. Attempting to ignore this issue does not erase the racial undertones present in the department, but instead reinforces and exacerbates the problem in the workplace. Harvard Business School Professor Mike Norton recently conducted a study which demonstrated that "playing the political correctness game" contributed to greater perception of racial bias than a blunt approach to racial disparity. Norton explained that in the double-blind test, black test subjects would later report that "if you're being so weird about not mentioning race, you probably have something to hide."

Norton suggests that companies and organizations that wish to decrease racial tension can do so by "stressing multiculturalism instead of racial colorblindness." 
He reports success in organizations that host events that validate the experiences of people from all ethnicities instead of treating all minority groups as "non-white." Similarly, in Norton's studies, organizations that engage in affirmative action policies and promote multicultural environments experience increased organizational effectiveness. These efforts would be beneficial in the Ferguson Police Department, where the spokesman apparently does not recognize the irony of correcting the public on the fact that out of 53 officers, there are an entire four black police officers instead of a mere three.

Case 3

"Pants Up, Don't Loot. I don't care if you're white, black, yellow, purple, whatever, if you're going at a cop you're not going to be getting up." -- Don Alexander, leader of a pro-Darren Wilson crowdfunding campaign to erect a 300 square foot billboard in downtown Ferguson with 10-foot tall letters featuring the hashtag: \#PantsUPdontLOOT.

Don Alexander wanted to send a message to the protesters in Ferguson, and felt that a four word billboard would best convey his thoughts. He found hundreds of supporters to crowdfund over $\$ 3000$ within the first few days of his original posting. In response to the "Hands Up, Don't Shoot" chant that became the mantra of protesters in North County St. Louis, this conservative blogger popularized the counter-slogan "Pants Up, Don't Loot." This chant was met with limited success at rallies, but was repeated online on the social media pages of Darren Wilson supporters. Through convoluted logic, the people who are outspoken against the protesters maintain that they are not looking at race, but simply the non-racial characteristics of the protesters, such as sagged pants. On the indiegogo.com crowdsourcing website, people who funded the project were able to post commentary which appears next to their funding amount. One donor, identified as 'winslowhomerclark' questioned the entire allegation of racism, stating "So now it's racist to tell people to wear clothes correctly and to not commit crimes?" From within a colorblind mindset, this logic makes sense: Because people of any race technically could wear sagged pants, targeting all those he has deemed to "wear clothing incorrectly" is not a racial issue, even if he only targets people of another race.

This focus on individual action while ignoring the intergroup dynamic reinforces the way that majority power groups dominate people who hold lower social status. Peggy McIntosh describes how the term privilege is not quite adequate to explain the position between white people from power groups and people of colour who experience less societal freedom. The term "privilege" connotes positive benefits which allow some people to enjoy nifty perks, whereas McIntosh recognizes systematic empowerment, which in turn "confers dominance, [and] gives permission to control, because of one's race" (McIntosh 1989: 349, emphasis hers). In the case of the billboard, privilege is what allows Don Alexander and his financial backers to feel comfortable policing the dress and grooming of black people while associating 
the way that their pants fit with the criminal acts of breaking and entering. This perspective is legitimized in the world around them, as police departments continue to write departmental protocol that codifies sagged ${ }^{3}$ pants $^{4}$ as gang ${ }^{5}$ attire ${ }^{6}$, news reports relentlessly associate sagging pants ${ }^{7}$ with prison $^{8}$ culture $^{9}$, and the President of the United States of America feels comfortable saying "brothers should pull up their pants. You're walking by your mother, your grandmother, and your underwear is showing. What's wrong with that? Come on." President Obama's remarks demonstrate that this sort of policing of fashion is not simply something that happens from external groups pressuring black people to conform to white standards, even if the President remains a far cry from being "internal" to the protesters in Ferguson.

Problematically, the second half of the \#PantsUPdontLOOT hashtag comes from decades of collective white reimagining of events labelled as riots and looting. When San Francisco Giants fans flooded the Castro and Embarcadero after their team won the World Series two months after the shooting of Mike Brown, cars were flipped and lit on fire, stores were broken into, and public busses were mobbed, derailed and destroyed by rioters. Few people involved in the riotous events were black, and this generally white group was not met with tear gas, rubber bullets and media reports about angry mobs. Instead, media reports about "shenanigans," ${ }^{10}$ "mischief" public damage. Sports riots such as these are relatively commonplace compared to racially-charged riots associated with protest events. The 2011 Vancouver Stanley Cup riot broke out when disappointed fans left the stadium after the Boston Bruins defeated the Vancouver Canucks. The ensuing riots caused nearly $\$ 5.13$ million in damages, in addition to 4 attempted murders, 140 people left wounded, and 9 police officers injured. By comparison, the estimated damage in Ferguson totals out around $\$ 4.5$ million, but of these two events, it is the one that became an international media icon of "criminals destroying their own city."

Similarly problematic media frames emerged after another riot in Keene, New Hampshire at a Halloween event known as Pumpkinfest. The media narratives repeatedly cut against Ferguson in one of two ways. When the two events were framed differently, they favoured the Keene rioters by downplaying their wrongdoing. When the events were both framed as riots, the civil disobedience from the oppressed community of Ferguson was brought down to the level of drunken frat kids. In any comparison of the media ecology surrounding coverage of Pumpkinfest to the coverage of Ferguson, it is essential to note that there are distinct differences between the two events. Dr. Donna Murch, a professor on race issues at Rutgers, points out that "Ferguson is a political movement, and looting in Keene is quite different from the civil disobedience we're seeing in Ferguson." Wanton destruction fueled by alcohol and bad decisions is obviously different than targeted acts of aggression as part of a racially-motivated protest. However, when media reports discuss rioters in Ferguson, racialized keywords that reinforce systems of privilege are used to describe protesters. Thugs are marching in the streets, not rowdy college 
kids. News anchors feel comfortable describing the protesters in Ferguson as animals instead of mischief makers. The protesters in Ferguson are cited as destroying their community instead of being labelled as booze-filled revelers. The way that the events are reported in the media significantly shape how political decisions are made, and change the public consciousness about the events.

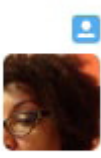

Olivia A. Cole and 2 others follow

Alysia S. Christiani @AlysiaSimone $\cdot 11 \mathrm{~m}$

Humph RT @seangirvan: Your media guide to the differences between

\#Ferguson and \#pumpkinfest (via @MattTW)
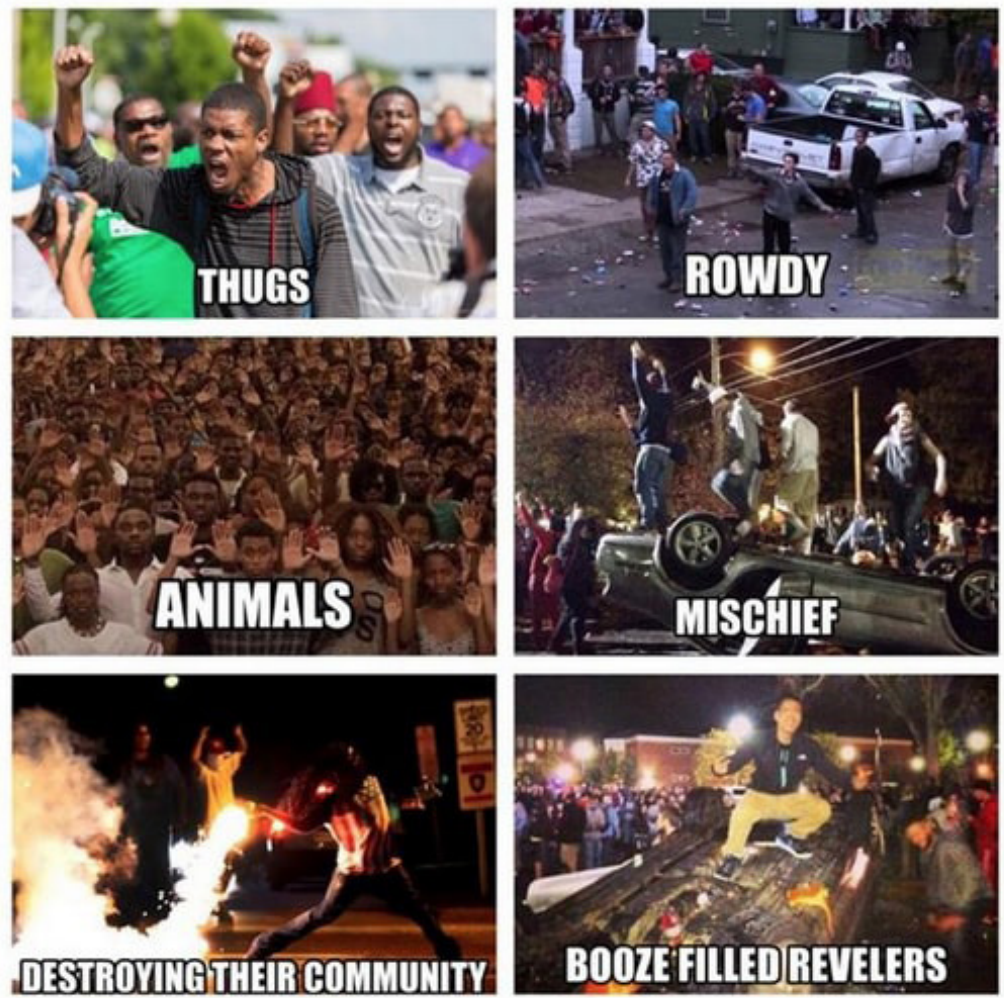

Image credit: Alysia S. Christiani, Twitter

Dr. Douglas McLeod explains that the two events are absolutely different, because Ferguson's protests result from "enduring, longstanding issues related to race and inequality," which has kept peaceful protesters out on the streets ever since the initial shooting. He finds the way that the two events have been described to be insulting and problematic, because "both instances were framed as narratives in which the media strove to maintain neutrality by depicting facts on the ground-what happened, who was there, how many arrests-essentially, a story pitting police against the crowd instead of going deep into the themes and issues." This is problematic 
and creates an unfair comparison, because as McLeod explains, "when we do that, the underlying message is, here's a group that was creating chaos or disrupting order, and the response of police was to restore order," even though he argues that the police were not attempting to fix the situation in Ferguson. He explains that "if there is justification for being upset about the coverage, it's the fact that the Ferguson situation was treated so much like the New Hampshire [one], not that they were treated differently. They were treated like they didn't have enduring issues or evidence to support their frustrations and claims." Under this context, the comparison is problematic because the domination described by McIntosh allows a frat party gone wild to be treated the same way as organized civil disobedience movements. Both events would have benefited from more substantial press coverage, as the corruption behind the Ferguson government only came to light after months of Department of Justice investigations, and the toxic culture of fraternities is only recently receiving media attention.

These examples demonstrate a flaw in the supposedly colorblind worldview that ostensibly claims to focus on individual actions and not race. The individual actions resulting in flipped cars, burnt buildings and destroyed public works are all comparable to destruction in the Ferguson rioting, however, commentary about the "people destroying their own community" plagues the social discourse about Ferguson. The focus on individual action is only maintained when the privileged group chooses to do so, and even more problematically, the actions of one individual can never be entirely separated from the groups with which they are associated. To pretend otherwise is inaccurate at best.

\section{Persistence of Inaccurate Colorblind Worldviews}

The perspectives embodied in these quotes receive significant media coverage and infiltrate national public perception, which reinforces the supposedly colorblind narratives. Media subscribers hear on the news that "race is not an issue in Ferguson" and that "the police aren't dealing with race issues, but criminal problems." In an ideal situation, these narratives would be compared to competing ideas, and more difficult nuances would emerge that build genuine understanding of the issues. So why does this not happen? According to a 2012 Public Religion Research Institute study, media consumers simply are not getting exposed to these competing narratives that would provide context and depth to racial issues. The polling data demonstrated that black Americans are much more likely than white Americans to discuss problematic issues in their community with others. Social media allows people to exist within an echo chamber. On average, the social media network for a white person usually consists of 91 per cent other white people, and over 75 per cent of white people have an exclusively white social network. Within these all-white communities, white people are 4-5 times more likely to believe that blacks and other minorities receive equal treatment from the criminal justice system. This allows pundits to ignore reality and play to their base's worldview instead of challenging 
them with new ideas and complex stories. To sum up the problem, Robert P. Jones explains that a significant "reason for the racial divide over Michael Brown's death is that white Americans tend to talk mostly to other white people."

This privilege to only associate within one's individual race is not something available for many minorities, even if they create their own filter bubble via their Facebook friends list. Most minorities do not associate exclusively with people from their own national origin, and certainly are not able to exclusively watch news presented by network anchors who share the colour of their skin. This is reinforced by Peggy McIntosh's first point of white privilege: that if she wants to, she can "arrange to be in the company of people of [her] own race most of the time" (McIntosh 1989: 346).

\section{Conclusion}

As the rhetoric surrounding discussions of race has shifted since the civil rights movement, colorblindness has ostensibly provided a non-racialized lens through which organizations can structure themselves to avoid disempowering any one group. Unfortunately, this narrative has instead allowed an oppressive structure to preserve privilege and reconstruct the narrative of race relations that passes as politically correct, but is inherently flawed. The goal of this essay is not to dismiss the notion of colorblindness in all social interactions, but to take seriously the implications of colorblind ideology in a broader mediated field.

The narrative of organizational colorblindness is intellectually dishonest and problematic, yet it remains unrelenting in the face of its own inaccuracy. Being the result of erstwhile progressive political perspectives, colorblind logic reifies social dynamics that oppress minorities. This is done through a selective interpretation of reality, which can only be done from a position of privilege. As the American nation continues to invoke Martin Luther King Jr.'s name in public policy, a more accurate perception of the problems inherent to colorblind thinking allows for more equitable public decisions to be made. Ferguson brings the false doctrine of colorblindness to the forefront, but also provides an opportunity for this narrative to be dismissed, or at the very least, applied with much more care than it received in the initial coverage following the shooting of Mike Brown in Ferguson.

\section{Notes}

1. Between 1970 and 1980, the city re-worked the demographic language and the term anglo was replaced with white/non-hispanic in official usage.

2. The town of Bellfontaine has one black officer out of 34 in a town with $73 \%$ black citizens, and the city next door, Florissant, has an entirely white police force. The city of Florissant has over 50,000 residents, and 71\% of the people pulled over by Florissant police in 2013 were black. An interactive chart demonstrating where police departments are racially dissimilar to the communities they serve can be found at: http://www. 
washingtonpost.com/wp-srv/special/national/police-staffing/

3. Dozens of police departments have specifically codified sagged pants as an indicator of gang membership; only a select few are noted here. Metro Gang Unit. "Gangster Clothing." Greater Salt Lake Unified Police Department. http://updsl.org/divisions/ metro_gang_unit/gangster_clothing

4. Olathe Police Department. "Is Your Child in a Gang?" Office of Juvenile Justice. http:// www.olatheks.org/files/police/Gangs_BasicInfoFlyer.pdf

5. Everett Police Department Community Outreach. "Gang Awareness: What to Know." Everett Police Department, Massachusetts. http://www.everettpolicema.com/gang_ awareness.htm

6. Los Angeles Police Department. "How are Gangs Identified?" Los Angeles Police Foundation. http://www.lapdonline.org/get_informed/content_basic_view/23468

7. Trice, Dawn Turner. "What do Baggy Pants Really Say?"

Chicago Tribune. http://articles.chicagotribune.com/2009-11-02/

news/0911010232_1_baggy-pants-wearing-thug-culture

8. Abdul-Karim, Shahid. "For some, sagging pants carry greater meaning."

Associated Press. http://www.washingtontimes.com/news/2014/jul/13/

for-some-sagging-pants-carry-greater-meaning/?page=all

9. Demby, Gene. "Sagging Pants And The Long History Of 'Dangerous'

Street Fashion." Code Switch - Frontiers of Race, Culture, and Ethnicity.

NPR. http://www.npr.org/blogs/codeswitch/2014/09/11/347143588/

sagging-pants-and-the-long-history-of-dangerous-street-fashion

10. Batey, Eve. "SFPD Braced For Shenanigans If The Giants Win Tonight." SFist. http://sfist.com/2014/10/16/sfpd_braced_for_shenanigans_if_the.php

11. Kaduk, Kevin. "San Francisco police seek to identify man who triggered burning of $\$ 1$ million city bus.” Yahoo! Sports. http://sports.yahoo.com/blogs/big-league-stew/sanfrancisco-police-seek-identify-man-triggered-burning-203448778--mlb.html.

12. Doyle, Rick. "San Francisco Giants Fans Riot In Streets After

World Series Win (Photos).” NESN. http://nesn.com/2014/10/

san-francisco-giants-fans-riot-in-streets-after-world-series-win-photos/

\section{References}

Alexander, Don. 2014. "Put up a billboard in downtown Ferguson saying \#pantsUPdontLOOT.” Indiegogo. https://www.indiegogo.com/projects/closed--172\#/

Alexander, Michelle and Cornel West. 2012. The New Jim Crow: Mass Incarceration in the Age of Colorblindness. New York Jackson, Tennessee: New Press, Perseus Distribution.

Anderson, Joel. 2014. "Is race an issue? Depends on who you ask."

Buzzfeed, 15 August. https://www.buzzfeed.com/joelanderson/

is-race-an-issue-in-ferguson-depends-on-who-you-ask 
Apfelbaum, Evan, Michael Norton \& Samuel Sommers. 2012. Racial Color Blindness : Emergence, Practice, and Implications. Current Directions in Psychological Science 21: 205-233.

Baldwin, Lewis. 2014. Distorted Images. The Domestication of Martin Luther King Jr. New York City: Cascade Books.

Bales, Robert. 1956. Family Socialization and Interaction Process. Boston, MA: Psychology Press.

Balko, Radley. 2014. How Municipalities in St. Louis County, Mo., Profit from Poverty. The Washington Post, 3 September. https://www.washingtonpost.com/news/the-watch/ wp/2014/09/03/how-st-louis-county-missouri-profits-from-poverty/

Ballard, Chris. 2011. The Kiss. Sports Illustrated, 26 December.

Barnes, Mario L. 2015. Judging Opportunity Lost: Assessing the Viability of Race-Based Affirmative Action after Fisher v. University of Texas. UCLA Law Review 62(2).

Berger, Peter \& Thomas Luckmann. 1966. The Social Construction of Reality: A Treatise in the Sociology of Knowledge. Garden City, NY: Anchor Books.

Berry, M.F. 1966. Vindicating Martin Luther King, Jr.: The road to a color-blind society. The Journal of Negro History 81(14): 137-144.

Blauner, Bob. 1989. Black Lives, White Lives: Three Decades of Race Relations in America. Berkeley: U of California Press.

Blauner, Bob. 1992. Black and White Languages of Race. Berkeley: U of California Press.

Bonilla-Silva, Eduardo, Carla Goar \& David G. Embrick. 2006. When Whites Flock Together: The Social Psychology of White Habitus. Critical Sociology 32(2-3): 229-253

Bostdorff, Denise M. \& Steven R. Goldzwig. 2005. History, Collective Memory, and the Appropriation of Martin Luther King Jr.: Reagan's Rhetorical Legacy. Presidential Studies

Quarterly 35(4): 661-690.

Bowen, Frances \& Kate Blackmon. 2003. Spirals of Silence: The Dynamic Effects of Diversity on Organizational Voice. Journal of Management Studies 40(6): 1393-1417.

Burke, Kenneth. 1966. Language as Symbolic Action. Berkeley \& Los Angeles: University of California Press.

Chappell, Bill. 2014. Obama: 'No Sympathy' for Those Destroying Ferguson. NPR News, 25 November. http://www.npr.org/sections/thetwo-way/2014/11/25/366650380/ obama-no-sympathy-for-those-destroying-ferguson

City of Ferguson. 2001. City History. http://www.fergusoncity.com/141/City-History

Crenshaw, Kimberle. 1989. Demarginalizing the Intersection of Race and Sex: A Black Feminist Critique of Antidiscrimination Doctrine, Feminist Theory and Antiracist Politics. The University of Chicago Legal Forum 140:139-167.

DelReal, Jose A. 2014. Michael Brown Memorial Destroyed Overnight. The Washington Post, 26 December. https:/www.washingtonpost.com/news/post-nation/wp/2014/12/26/ auto-draft/

DiTomasso Nancy, Rochelle Parks-Yancy \& Corinne Post. 2007. White Views of Civil Rights. In Intersections of Gender, Race, and Class, edited by Marcia Segal \& Theresa Martinez. Los Angeles, CA: Roxbury Publishing: 221-248. 
Dovidio, John \& Samuel Gaertner. 2004. Aversive Racism. In Advances in Experimental Social Psychology edited by James Olson \& Mark Zanna. Oxford: Academic Press.

Ellis, Don. 2006. Transforming Conflict: Communication and Ethnopolitical Conflict. New York: Rowman \& Littlefield.

Firozi, Paulina. 2014. 5 Things to Know About Ferguson Police Department. USA Today. 14 August. http://www.usatoday.com/story/news/nation-now/2014/08/14/ ferguson-police-department-details/14064451/

Gliha, Lori Jane \& Sameen Amin. 2014. Ferguson Mayor: I Regret Saying there was No Racial Divide. Al Jazeera America, 17 November. http://america.aljazeera.com/watch/ shows/america-tonight/articles/2014/11/17/ferguson-mayor-iregretsayingtherewasnoraci aldivide.html

Greenwald, Anthony G. \& Mahzarin R. Banaji. 1995. Implicit Social Cognition: Attitudes, Self-esteem, and Stereotypes. Psychological Review 102(1): 4-27.

Grinberg, E. 2014.Why Pumpkin Fest Riots are not like Ferguson. CNN, 21 October. http://www.cnn.com/2014/10/21/living/keene-pumpkinfest-riot-ferguson

Haberman, Clyde. 2008. Can Obama Help Kill Baggy Pants Look? New York Times, 14 November. http://www.nytimes.com/2008/11/14/nyregion/14nyc.html?_r=0

Hall, Stuart. 1994. Some 'Politically Incorrect' Pathways through PC, in The War of the Words: The Political Correctness Debate edited by Sarah Dunant, London: Virago Press.

hooks, bell. 1981. Ain't I a Woman? Black Women and Feminism. Boston, MA: South End Press.

Houston, Marsha and Julia Wood. 1996. Difficult Dialogues, Expanded Horizons: Communicating Across Race and Class. Ann Arbor: U of Maryland Press.

Jackman, Mary. 1996. The Velvet Glove: Paternalism and Conflict in Gender, Class, and Race Relations. Los Angeles: University of California Press.

Jackson, Ronald L. 1998. White space, White Privilege: Mapping Discursive Inquiry Into the Self. Quarterly Journal of Speech 85: 38-54.

Jones, Robert \& Daniel Cox. 2012. Beyond Guns and God: Understanding the Complexities of the White Working Class in America. Public Research Institute. http:// www.prri.org/wp-content/uploads/2012/09/WWC-Report-For-Web-Final.pdf

Jones, Robert P. 2014. Self-segregation: Why it's So Hard for Whites to Understand Ferguson. The Atlantic., 21 August. http://www.theatlantic.com/national/archive/2014/08/ self-segregation-why-its-hard-for-whites-to-understand-ferguson/378928/

Karst, Kenneth \& Harold Horowitz. 1974. Affirmative Action and Equal Protection. Virginia Law Review 60(6): 955-974.

King Jr., Martin Luther. 1986. The Autobiography of Martin Luther King Jr., edited by Clayborne Carson. New York: Grand Central Publishing.

Kramarae, Cheris. 1996. Classified Information: Race, Class, and (Always) Gender. In Gendered Relationships edited by Julia Wood. Mountain View: Mayfield Press.

Mazzocco, Philip J., Lyndsee W. Cooper \& Mariagrace Flinter. 2012. Different Shades of Racial Colorblindness: The Role of Prejudice, Group Processes E Intergroup Relations 15(2): 167-178. 
McGinley, Ann. 1997. Favoritism and Discrimination. Arizona Law Review. Phoenix: University of Arizona.

McIntosh, Peggy. 2007. White Privilege and Male Privilege: A Personal Account of Coming to See Correspondences Through Work in Women's Studies. In Intersections of Gender, Race and Class edited by Marcia Texler Segal and Theresa A. Martinez. Los Angeles: Roxbury Press.

Morton, Thomas \& Stefanie Sonnenberg. 2011. When History Constrains Identity: Expressing the Self to Others Against the Backdrop of a Problematic Past. European Journal of Social Psychology 41: 232-240.

Neville, Helen A., Roger L. Worthington \& Lisa B. Spanierman. 2001. Race, Power, and Multicultural Counseling Psychology: Understanding White Privilege and Color-blind Racial Attitudes. In Handbook of Multicultural Counseling (2nd ed.) edited by Joseph G. Ponterotto, J. Manuel Casas, Lisa A. Suzuki and Charlene M. Alexander. Thousand Oaks, CA: Sage Publications.

Noelle-Neumann, Elizabeth. 1993. The Spiral of Silence. Chicago, IL: University of Chicago Press.

Norton, Michael I., Samuel R. Sommers, Evan P. Apfelbaum, Natassia Pura, and Dan Ariely. 2012. Color Blindness and Interracial Interaction: Playing the Political Correctness Game. Psychological Science 17(11): 949-53.

Norton, Michael I., Joseph A. Vandello \& John M. Darley. 2004. Casuistry and Social Category Bias. Journal of Personality and Social Psychology 87(6): 817-31.

Oates, Stephen B. 1994. Let the Trumpet Sound: A Life of Martin Luther King, Jr. Stanford: Harper Perennial.

Pariser, Eli. 2011. The Troubling Future of Internet Search. The Futurist 45(5): 6-8.

Patterson, Thomas C. 1997. Inventing Western Civilization. New York: Monthly Review Press.

Poteat, V. Paul \& Lisa B. Spanierman. 2012. Modern Racism Attitudes Among White Students: The Role of Dominance and Authoritarianism and the Mediating Effects of Racial Color-blindness. The Journal of Social Psychology 152(6): 758-74.

Sanders, Katie. 2014. Ferguson, Mo., has 50 White Police Officers, Three black officers, NBC's Mitchell Claims. Tampa Bay Times: Politifact. 17 August. http:// www.politifact.com/punditfact/statements/2014/aug/17/andrea-mitchell/ ferguson-police-department-has-50-white-officers- $t$ /

Sayer, Andrew. 2000. Realism and Social Science. London: Sage.

Smith, Donald H. 1960. An Exegesis of Martin Luther King, Jr.'s Social Philosophy. Atlanta, GA: Clark Atlanta University.

The Daily Show with Jon Stewart. 2012. Bill O'Reilly Extended Interview. Comedy Central. http://thedailyshow.cc.com/extended-interviews/i11p92/ bill-o-reilly-extended-interview

Thurman, Neil \& Steve Schifferes. 2012. The Future of personalization at News Websites: Lessons from a Longitudinal Study. Journalism Studies 13(5-6): 1-18

Topaz, Jonathan. 2014.Ferguson Mayor: No 'Racial Divide.' Politico, 19 August. http:// www.politico.com/story/2014/08/ferguson-mayor-james-knowles-race-110147.html 
Weinecke, Matt. 2014. Your Media Guide to the Differences Between \#Ferguson and \#Pumpkinfest. Twitter. 2014, 14 October. https://twitter.com/AlysiaSimone/ status/523972273653710848.

Williams, Raymond. 1976. Keywords: A Vocabulary of Culture and Society. London: Fontana.

Williams, Raymond. 1981. The Sociology of Culture. Chicago, IL: University of Chicago Press.

Wu, Frank H. 2003. East is East, East is West. Yellow: Race in America Beyond Black and White. NY: Basic Books. 